\title{
Penentuan Lintasan Pergerakan Quadcopter Berbasis GPS (Global Positioning System)
}

\author{
Abdur Rohman Harits Martawireja, Hadi Supriyanto \\ Jurusan Otomasi Manufaktur dan Mekatronika, Politeknik Manufaktur Bandung \\ Email: harits@polman-bandung.ac.id
}

\begin{abstract}
Informasi Artikel:
ABSTRAK

Received:

7 Agustus 2019

Accepted :

23 September 2019

Available

23 Desember 2019

UNMANNED AERIAL VEHICLE (UAV) merupakan sebuah kendaraan udara tanpa awak yang dapat dikendalikan. Terdapat dua tipe UAV, yakni fixed wing dan rotary wing. Quadcopter menjadi salah satu tipe UAV rotary wing yang banyak digunakan dalam berbagai kebutuhan, seperti eksplorasi dan pengambilan citra. Pada penelitian ini Quadcopter berfungsi sebagai kendaraan yang harus bergerak mengikuti lintasan, dimana lintasan yang dikuti oleh Quadcopter berasal dari GPS yang dihasilkan oleh objek yang diikuti (Modul Utama). Tipe GPS yang terpasang pada Quadcopter (GPS1) maupun pada Modul Utama (GPS2) adalah GPS Ublox NEO. Prinsip kerja sistem adalah quadcopter mengikuti Koordinat-koordinat lintasan yang dihasilkan oleh GPS1, di mana data-data lintasan GPS1 dikirim ke Quadcopter menggunakan media Bluetooth. Dalam pergerakannya, Quadcopter akan terus-menerus membandingkan data-data koordinat yang dihasikan posisi Quadcopter dengan data-data koordinat lintasan yang sudah diterima. Pengujian pada Receiver GPS Modul Utama (GPS1) dan Receiver GPS Quadcoter (GPS2), kedua GPS mampu mendapatkan data GPS dari satelit. Kesalahan/perbedaan data dari GPS1 dan GPS2 pada pengujian pergerakkan Quadcopter untuk mengikuti Modul Utama sebagai titik tujuan sebesar $53 \%$ pada garis lintang dan $51 \%$ pada garis bujur.
\end{abstract}

\section{Kata Kunci:}

UAV

Quadcopter

GPS

Bluetooh Module

Latitude

Longitude

\section{ABSTRACT}

UNMANNED AERIAL VEHICLE (UAV) is an aerial vehicle without pilot that can be controlled. There are two types of UAV, fixed wing and rotary wing. Quadcopter becomes one of rotary wing type UAV that is commonly used in various needs, like exploration and imaging. In this study, Quadcopter is used as the vehicle that moves following the path produced by the GPS on followed objek (main modul). The type of the GPS installed on Quadcopter (GPS1) and main modul (GPS2) are GPS Ublox NEO. The working principle of the system is Quadcopter follows the track coordinates generated by GPS1, which GPS1 track data is sent to the Quadcopter using Bluetooth media. While the Quadcopter moves, it will continuously compare the coordinate data produced by the Quadcopter's position with the track coordinate data that had been received. Testing on the Main Module GPS Receiver (GPS1) and GPS Receiver Quadcoter (GPS2), both GPS is able to get GPS data from satellites, but data can be lost or deviated in confined spaces. Error / difference in data from GPS1 and GPS2 in Quadcopter movement testing to follow the Main Module as the destination point at latitude and longitude, respectively, are 53\% and $51 \%$. 


\section{Pendahuluan}

Perkembangan ilmu pengetahuan dan teknologi di bidang navigasi dan robotika kini sangat cepat. Teknologi pada dasarnya dikembangkan untuk membantu manusia dalam melakukan suatu pekerjaan tertentu, seperti penentuan posisi yang akurat, kendaraan dengan kecepatan yang tinggi dan pekerjaan yang beresiko tinggi. Salah satu perkembagan di bidang navigasi yaitu pemanfaatan GPS (Global Positioning System). Informasi dari GPS dapat dimanfaatkan untuk mengetahui posisi geografis yang menunjukkan titik koordinat dari sebuah objek. GPS banyak dimanfaatkan untuk mengetahui rute perjalanan dari satu tempat ke tempat lain serta jarak tempuh dari rute tersebut [1].

Salah satu perkembangan teknologi di bidang robotika adalah UAV (Unmanned Aerial Vehicle). UAV merupakan sebuah kendaraan udara tanpa awak yang dapat dikendalikan. Terdapat dua tipe UAV, yakni fixed wing dan rotary wing. Salah satu jenis UAV rotary wing ialah quadcopter. Quadcopter banyak digunakan pada bidang eksplorasi, pengambilan citra, juga untuk pengamatan[2].

Sistem otomatis merupakan sistem yang mengurangi campur tangan manusia serta meringankan pekerjaan manusia. Pada saat ini terdapat sistem otomatis dari quadcopter yang bergerak berdasarkan sistem yang telah terprogram dengan memasukkan data koordinat posisi yang perlu dilewati oleh quadcopter tersebut tanpa harus mengendalikannya secara manual.

Berdasarkan hal tersebut maka pada penelitian ini akan dibuat sistem otomatis gerak quadcopter dengan memanfaatkan receiver GPS pada pengguna dan juga quadcopter. Data receiver GPS 1 dijadikan titik tujuan untuk quadcopter sedangkan receiver GPS 2 pada quadcopter digunakan untuk mengetahui lokasi dari quadcopter itu sendiri serta dijadikan sebuah sensor umpan balik pada sistem pengendalian pergerakkan quadcopter. Diharapkan quadcopter secara otomatis akan bergerak mendekati titik tujuan. Perangkat bluetooth akan digunakan sebagai alat komunikasi untuk mengirim dan penerima data antara modul pengguna dan quadcopter. Hasil yang diharapkan dari penelitian ini adalah sistem dapat mengetahui posisi yang didapatkan dari GPS dan quadcopter dapat bergerak menuju titik tujuan, yakni titik koordinat pengguna.

\section{PERANCANGAN Sistem}

Gambar 1 menunjukkan sistem yang akan dibuat. Tiap modul GPS mendapatkan data koordinat posisi dari satelit. Pada modul GPS 1 di user, hasil posisi akan diolah di mikrokontroller dan dikirimkan dengan modul bluetooth ke modul bluetooth di quadcopter. Posisi dari modul GPS 1 pada user akan dibanding dengan posisi dari Modul GPS 2 di quadcopter. Hasil dari pengolahan data oleh mikrokontroler yaitu selisih jarak dari modul GPS 1 user dan modul GPS 2 quadcopter akan digunakan sebagai parameter pergerakkan quadcopter. Secara keseluruhan system ini terdiri dari 1 buah quadcopter, 2 buah modul GPS, 2 buah modul Bluetooth, dan 2 buah mikrokontroller. 


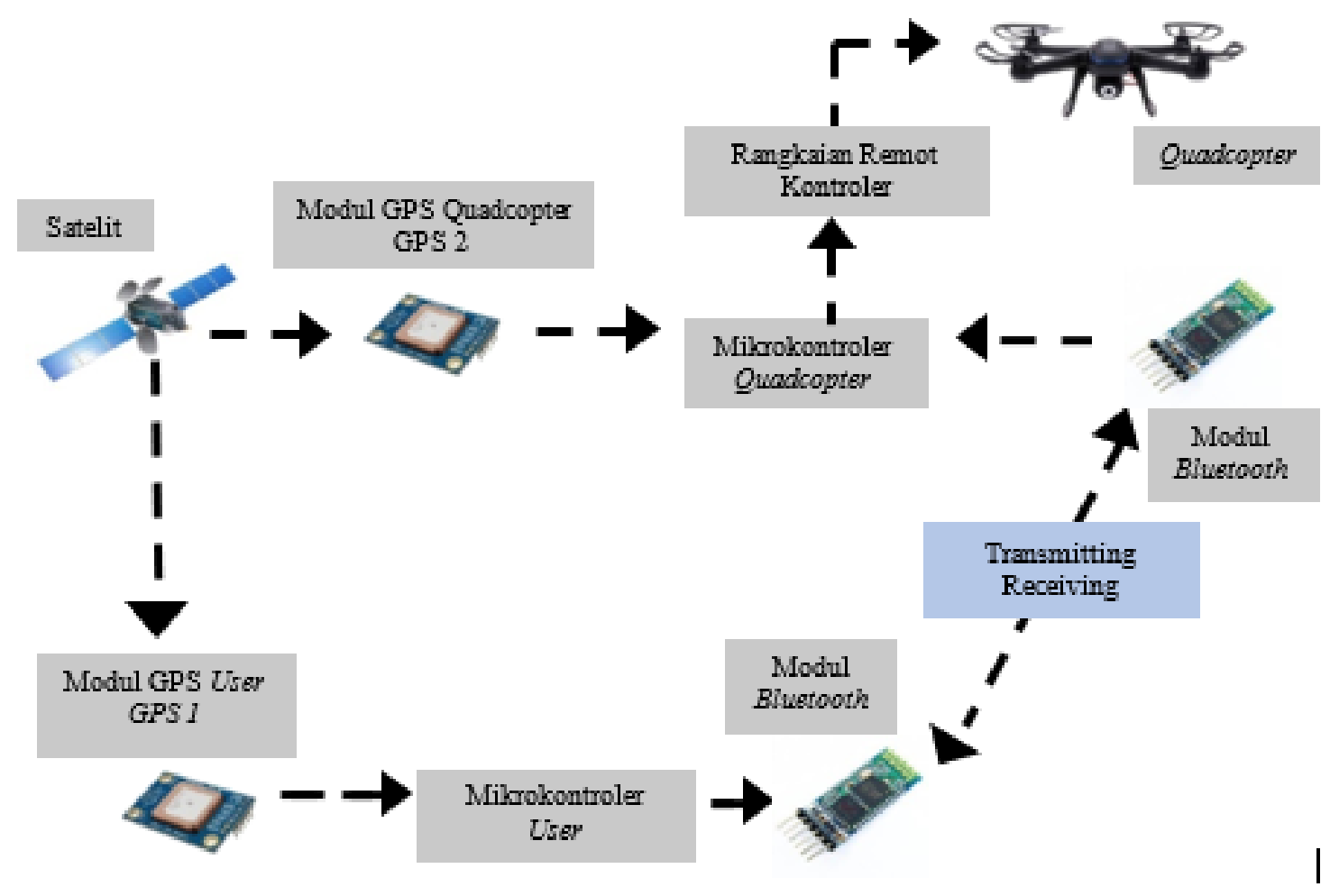

Gambar 1. Arsitektur Sistem

\subsection{Pembuatan Perangkat Keras}

\subsubsection{Mikrokontroler Arduino Pro Mini}

Terdapat dua Arduino Pro Mini pada penelitian ini yang dijadikan pengendali untuk pengambilan data GPS dari receiver GPS dan melakukan perhitungan selisih pergerakkan dari quadcopter. Arduino Pro Mini ditunjukkan pada Gambar 2.

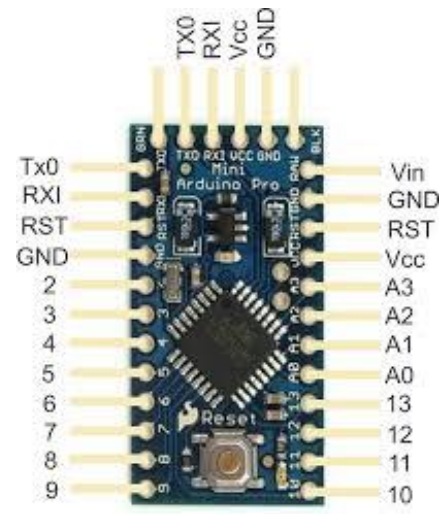

Gambar 2. Konfigurasi Pin Arduino Pro Mini 


\subsubsection{Receiver GPS Ublox-Neo}

Terdapat dua modul GPS yang digunakan pada penelitian ini, yakni GPS Ublox-Neo 6M sebagai GPS 1 user dan GPS U-blox-Neo 7M sebagai GPS 2 quadcopter. Gambar 2 menunjukkan kedua buah GPS yang digunakan. Kedua receiver GPS digunnakan untuk mengambil data posisi modul, modul utama dan modul quadcopter. GPS Neo-7m yang digunakan bisa menentukan lokasi dengan 5 tipe penerimaan (56 Channels, GPS L1C/A, SBAS L1C/A, QZSS L1C/A, Galileo E1B/C). keakuratan GPS ini di posisi horizontal sekitar 2.5m [3].

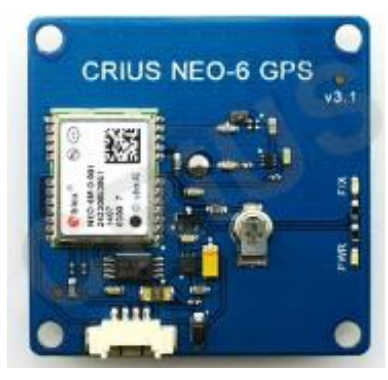

(a)

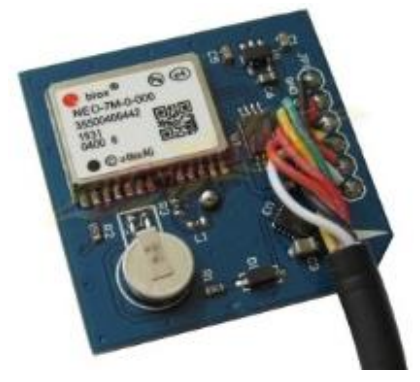

(b)

Gambar 3. Receiver GPS Ublox (a) Neo 6M dan (b) Neo 7M

Data yang didapatkan dari GPS berformat data NMEA-0183. Salah satu dari baris data tersebut adalah baris \$GPGGA yaitu sebagai berikut:

\$GPGGA, 092204.999,4250.5589, S, 14718.5084, E, 1,04,24.4,19.7, M, , , 0000* $1 \mathrm{~F}$.

Tabel 1. Data GPS untuk Jenis Kalimat GPGGA

\begin{tabular}{ccc}
\hline No & Jenis Data & GPGAA \\
\hline 1 & Time (UTC) & 092204.99 \\
\hline 2 & Latitude & $4250.5589, \mathrm{~S}$ \\
\hline 3 & Longitude & $14718.5084, \mathrm{E}$ \\
\hline 4 & Fix Quality (invalid, GPS fix, DGPS fix) & 1 \\
\hline 5 & Number Of Satelite & 04 \\
\hline 6 & Horizontal dilution of position & 24.4 \\
\hline 7 & Altitude & $19.7, \mathrm{M}$ \\
\hline 8 & Height of geoid above WGS84 ellipsoid & $($ empty field) \\
\hline 9 & Time since last DGPS update & $($ empty field) \\
\hline 10 & DGPS reference station id & $($ empty field) \\
\hline 11 & Checksum & $0000 * 1 \mathrm{~F}$ \\
\hline 12 & Status (A=active or V=Void) & - \\
\hline 13 & Speed over the ground in knots & - \\
\hline 14 & Track angle in degrees True & - \\
\hline 15 & Magnetic Variation & - \\
\hline 16 & Date & - \\
\hline
\end{tabular}


Tabel 1 menjelaskan data GPS yang ada pada baris GPGAA[4]. Pada penelitian ini data NMEA dari GPS diolah kembali menggunakan library Tiny GPS++ memakai metode parsing data. Data yang digunakan adalah data garis lintang (latitude) dan garis bujur (longitude).

\subsubsection{Bluetooth HC-05}

Modul bluetooth digunakan sebagai alat komunikasi nirkabel antara quadcopter dengan modul pengguna. Dua bluetooth yang digunakan disinkronisasikan menggunakan AT Command. Bluetooth HC-05 dipilih karena memiliki fitur sebagai mode master dan slave [5], sehingga akan lebih fleksibel untuk digunakan. Konfigurasi pin serial modul bluetooth HC-05 ditunjukkan pada Gambar 4.

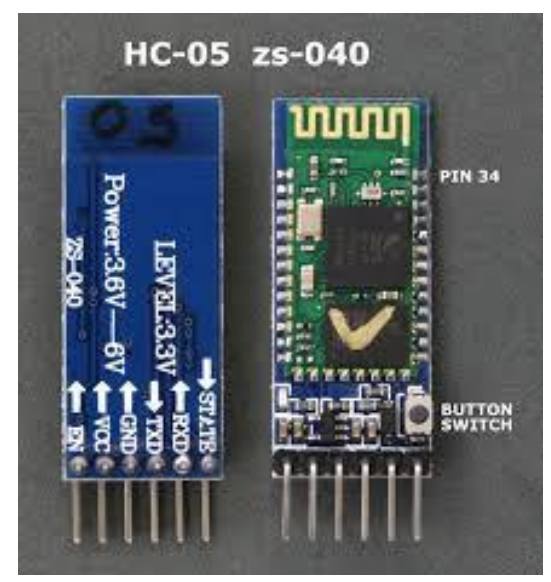

Gambar 4. Bluetooth HC-05

\subsubsection{Quadcopter Blackhawk SQ800C}

Quadcopter Blackhawk SQ800C seperti yang terlihat pada Gambar 5 digunakan sebagai aktuator pada penelitian ini. Quadcopter ini dipilih karena memiliki fitur yang umum pada sebuah quadcopter, seperti pergerakkan yaw, pitch, dan roll. Telah dilengkapi pula dengan sebuah remot kontroler untuk menggerakkan quadcopter secara manual.

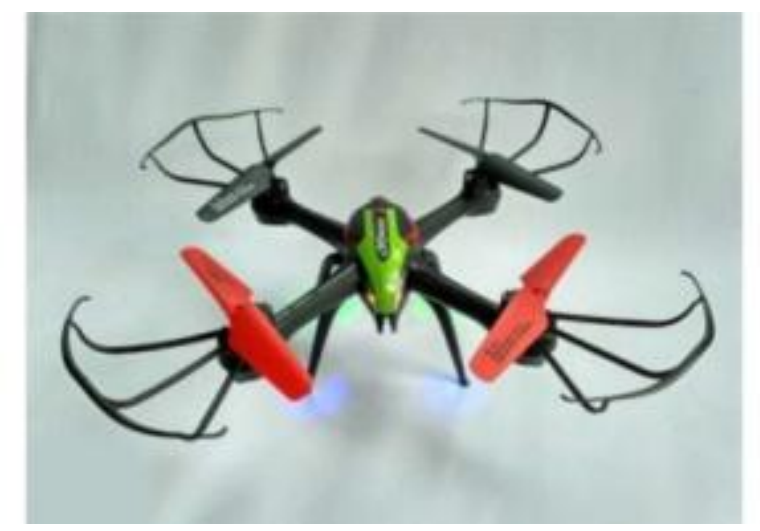

Gambar 5. Quadcopter Blackhawk SQ800C 


\subsection{Pembuatan Perangkat Lunak}

Diagram alir program untuk menunjang hardware terlihat pada Gambar 6. Ketika sistem dimulai, kedua power yang terdapat pada modul utama dan quadcopter dinyalakan. Modul utama mengirimkan permintaan data koordinat dari quadcopter. Lalu quadcopter akan mengirimkan data longitude dan latitude ke pada modul utama. Komunikasi keduanya menggunakan bluetooth sebagai perangkat komunikasinya. Selanjutnya, modul utama akan mengambil lokasi dari GPS di modul utama, lalu memparsing data GPS quadcopter dan GPS modul utama. Hasilnya akan di dapat dua pasang koordinat, koordinat garis bujur dan garis lintang modul utama dan quadcopter.

Arah utara dari receiver GPS 2 pada quadcopter telah ditentukan terlebih dahulu, sehingga hasil nilai positif dan negatif GPS akan sesuai dengan arah utara yang telah ditentukan. Pergerakkan pertama yang diperintahkan pada quadcopter ialah maju atau mundur, hingga garis bujur modul utama dan quadcopter telah sama. Jika nilai garis bujur telah sama, maka quadcopter akan diperintahkan untuk bergerak ke kanan atau ke kiri hingga nilai garis lintang modul utama dan quadcopter sama. Jika nilai garis lintang telah sama, maka quadcopter akan diperintahkan untuk berhenti bergerak. 


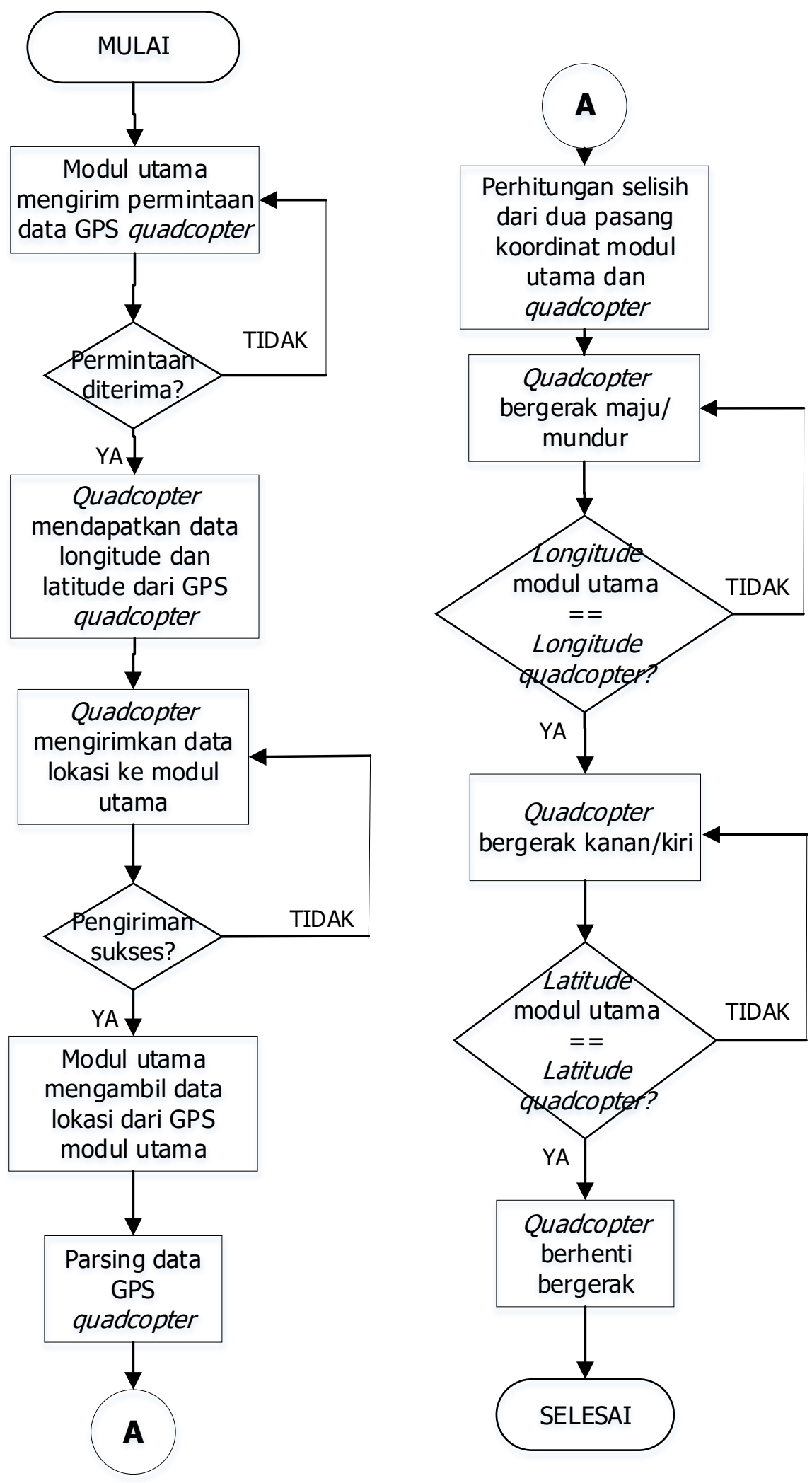

Gambar 6. Diagram alir program 


\section{HASIL IMPLEMENTASI SISTEM}

\subsection{Pengujuan Receiver GPS 1 Sebagai Sensor Posisi}

Pengujian pertama dilakukan untuk mengetahui kemampuan dari receiver mendapatkan data garis lintang dan garis bujur dari satelit. Percobaan ini dilakukan sebanyak dua kali.

Tabel 2. Data GPS pengujian receiver GPS 1 sebagai sensor

\begin{tabular}{ccc}
\hline No & Latitude & Iongitude \\
\hline 1. & -6.8762187 & 107.6217498 \\
\hline 2. & -6.8761281 & 107.6217575 \\
\hline 3. & -6.8760409 & 107.6217575 \\
\hline 4. & -6.8760523 & 107.6216735 \\
\hline 5. & -6.8760719 & 107.6215744 \\
\hline 6. & -6.8761358 & 107.6215362 \\
\hline 7. & -6.8762392 & 107.6215438 \\
\hline 8. & -6.8762879 & 107.6216201 \\
\hline 9. & -6.8762893 & 107.6215972 \\
\hline 10. & -6.8762660 & 107.6217727 \\
\hline
\end{tabular}

Pada Tabel 2, data-data garis lintang dan garis bujur dari receiver GPS 1 di user. Data-data pada tabel di atas merupakan sampel sebanyak 10 data dari keseluruhan data sebanyak 124. Keseluruhan data tersebut divisualisasikan pada Google Maps dengan menampilkan titik-titik koordinat dari tabel, seperti yang terlihat pada Gambar 7.

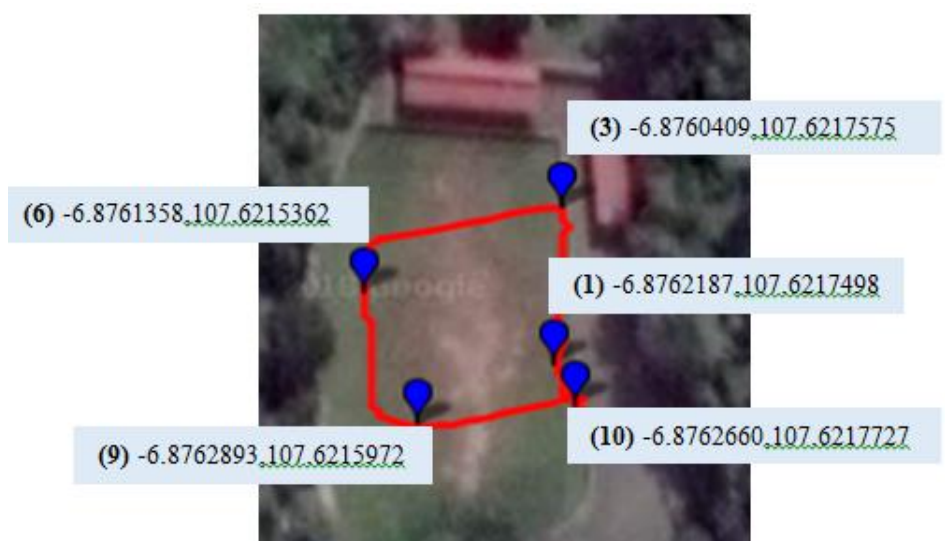

Gambar 7. Pengujian receiver GPS 1 sebagai sensor posisi

Percobaan kedua adalah percobaan pada ruang terbuka dan tertutup. Data yang didapat diperlihatkan pada Tabel 3. Pada percobaan ini terjadi data hilang dan data yang menyimpang pada ruang tetutup. Tabel 3 menampilkan data-data GPS yang divisualisasikan pada Gambar 8.

Tabel 3. Data GPS pengujian receiver GPS 1 pada ruang terbuka dan tertutup 
Penentuan Lintasan Pergerakan Quadcopter Berbasis GPS (Global Positioning System)

\begin{tabular}{ccc}
\hline No & Latitude & Iongitude \\
\hline 1. & -6.8774595 & 107.6205139 \\
\hline 2. & -6.8773779 & 107.6204681 \\
\hline 3. & -6.8773946 & 107.6204223 \\
\hline 4. & -6.8774099 & 107.6204757 \\
\hline 5. & -6.8773298 & 107.6203231 \\
\hline 6. & -6.8773779 & 107.6203689 \\
\hline 7. & -6.8776841 & 107.6199798 \\
\hline 8. & -6.8774824 & 107.6198348 \\
\hline 9. & -6.8771724 & 107.6197738 \\
\hline 10. & -6.8771157 & 107.6199417 \\
\hline 11. & -6.8767347 & 107.6200256 \\
\hline 12. & -6.8764538 & 107.6200332 \\
\hline 13. & -6.8765707 & 107.6201248 \\
\hline 14. & -6.8766589 & 107.6203460 \\
\hline 15. & error & error \\
\hline 16. & error & error \\
\hline 17. & -6.8764762 & 107.6201705 \\
\hline 18. & -6.8764324 & 107.6200485 \\
\hline 19. & -6.8764095 & 107.6200180 \\
\hline 20. & -6.8760876 & 107.6199340 \\
\hline
\end{tabular}

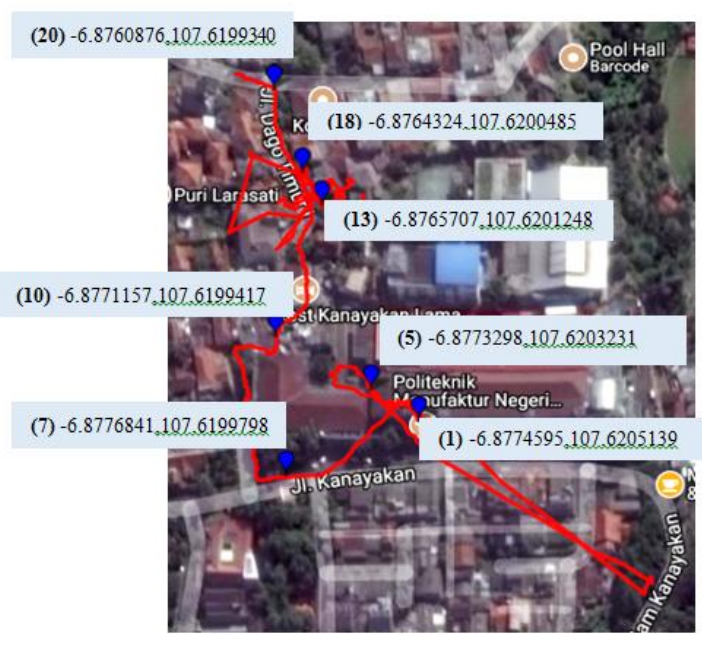

Gambar 8. Pengujian receiver GPS 1 di user pada ruang terbuka dan tertutup

\subsection{Pengujian Receiver GPS 2 Sebagai Sensor Posisi}

Pengujian ketiga dilakukan agar dapat diketahui kemampuan dari receiver GPS 2 mendapatkan data garis lintang dan garis bujur dari satelit. Percobaan ini dilakukan sebanyak dua kali.

Tabel 4. Data GPS pengujian receiver GPS 2 sebagai sensor posisi

\begin{tabular}{ccc}
\hline No & Latitude & longitude \\
\hline 1. & -6.8762583 & 107.6217803 \\
\hline
\end{tabular}




\begin{tabular}{ccc}
\hline No & Latitude & longitude \\
\hline 2. & -6.8760504 & 107.6217117 \\
\hline 3. & -6.8760685 & 107.6216125 \\
\hline 4. & -6.8761162 & 107.6215362 \\
\hline 5. & -6.8762235 & 107.6215438 \\
\hline 6. & -6.8762989 & 107.6215972 \\
\hline 7. & -6.8762917 & 107.6216201 \\
\hline 8. & -6.8762817 & 107.6217193 \\
\hline 9. & -6.8762784 & 107.6217803 \\
\hline 10. & -6.8762845 & 107.6217880 \\
\hline
\end{tabular}

Data-data ditampilkan pada Tabel 4 untuk percobaan pertama sebanyak 10 data sebagai sampel dari 131 data yang divisualisasikan pada Google Maps seperti yang terlihat pada Gambar 9.

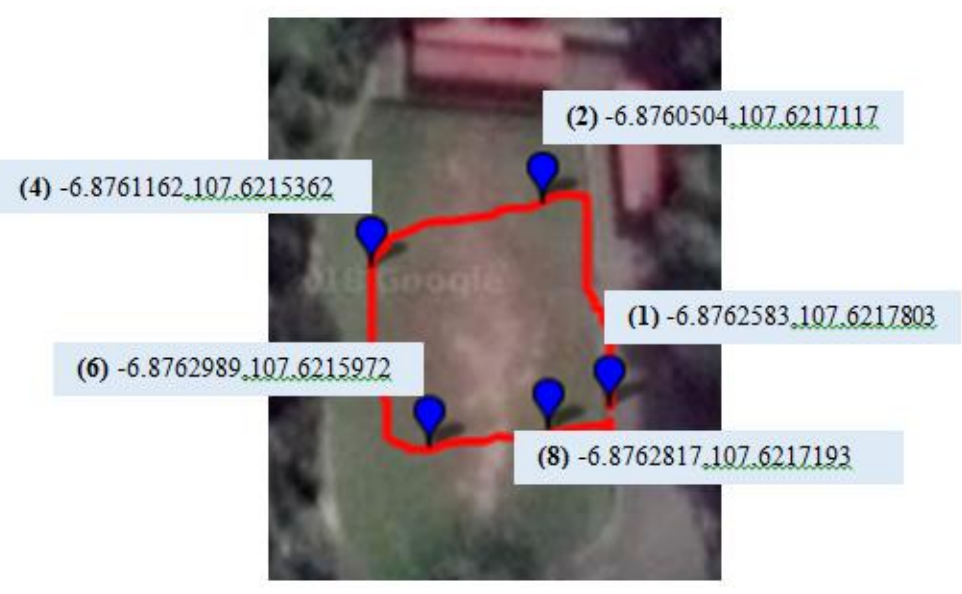

Gambar 9. Pengujian receiver GPS 2 percobaan sebagai sensor posisi

Tabel 5 menampilkan data-data GPS yang didapatkan dalam pengujian di ruang terbuka dan tertutup dalam satu kali perjalanan. Data-data tersebut divisualisasikan pada Google Maps yang ditunjukkan pada Gambar 10. Dapat terjadi data hilang dan data yang menyimpang jika pada ruang tertutup.

Tabel 5. Data GPS pengujian receiver GPS 2 pada ruang terbuaka dan tertutup

\begin{tabular}{ccc}
\hline No & Latitude & longitude \\
\hline 1. & -6.8774232 & 107.6203918 \\
\hline 2. & -6.8772406 & 107.6202087 \\
\hline 3. & -6.8774261 & 107.6204299 \\
\hline 4. & -6.8772587 & 107.6204681 \\
\hline 5. & -6.8776850 & 107.6200408 \\
\hline 6. & -6.8776054 & 107.6198196 \\
\hline 7. & -6.8773794 & 107.6198043 \\
\hline 8. & -6.8771734 & 107.6198348 \\
\hline 9. & -6.8770289 & 107.6199874 \\
\hline
\end{tabular}


Penentuan Lintasan Pergerakan Quadcopter Berbasis GPS (Global Positioning System)

\begin{tabular}{ccc}
\hline No & Latitude & longitude \\
\hline 10. & -6.8767056 & 107.6200103 \\
\hline 11. & -6.8764662 & 107.6200180 \\
\hline 12. & -6.8765335 & 107.6200866 \\
\hline 13. & error & error \\
\hline 14. & error & error \\
\hline 15. & -6.8765764 & 107.6201171 \\
\hline 16. & -6.8764400 & 107.6203155 \\
\hline 17. & -6.8765230 & 107.6200942 \\
\hline 18. & -6.8764305 & 107.6200561 \\
\hline 19. & -6.8762445 & 107.6199264 \\
\hline 20. & -6.8760495 & 107.6198654 \\
\hline
\end{tabular}

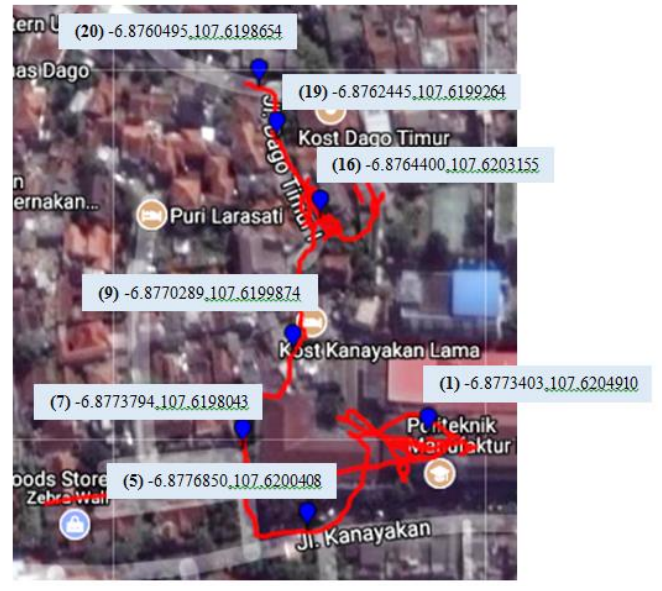

Gambar 10. Pengujian receiver GPS 2 pada ruang terbuka dan tertutup

\subsection{Lama Pengujian Quadcopter}

Pengujian terbang quadcopter ditunjukkan pada Tabel 6. Pengujian ini dilakukan dengan tujuan untuk mengetahui kemampuan dari baterai 3,7 V dengan 1200 mAh yang digunakan. Quadcopter diterbangkan manual menggunakan remot kontroler secara terus menerus sampai mencapai batas maksimal daya terbang quadcopter.

Tabel 6. Pengujian lama terbang quadcopter

\begin{tabular}{ccc}
\hline No & Waktu (menit) & Keterangan \\
\hline 1. & 3.00 & Quadcopter terbang \\
\hline 2. & 12.00 & Quadcopter terbang \\
\hline 3. & 21.32 & Quadcopter terbang melambat \\
\hline 4. & 23.37 & Quadcopter berhenti \\
\hline
\end{tabular}




\subsection{Pengujian Integrasi Untuk Receiver GPS}

Pengujuan Integrasi bertujuan untuk mengetahui kemampuan dari sistem melakukan skenario dari percobaan, yakni pemanfaatan GPS untuk pengambilan data titik koordinat yang akan dijadikan masukan sistem pergerakkan quadcopter dalam melakukan perpindahan untuk mendekati titik tujuan dimana pengguna berada. Tabel 7 adalah hasil pengujian integrase untuk variasi jarak 3,5 meter.

Tabel 7. Data GPS pengujian integrasi pada variasi jarak 3,5 meter

\begin{tabular}{|c|c|c|c|c|c|c|}
\hline \multirow[b]{2}{*}{ No } & \multicolumn{3}{|c|}{ Latitude } & \multicolumn{3}{|c|}{ Longitude } \\
\hline & $\begin{array}{c}\text { Seharusnya } \\
\text { (m) }\end{array}$ & $\begin{array}{c}\text { Aktual } \\
(\mathbf{m})\end{array}$ & Error & $\begin{array}{c}\text { Seharusnya } \\
\text { (m) }\end{array}$ & $\begin{array}{c}\text { Aktual } \\
(\mathbf{m})\end{array}$ & Error \\
\hline 1. & 3.50 & 5.60 & $60 \%$ & 3.50 & 5.50 & $57 \%$ \\
\hline 2. & 3.50 & 4.61 & $32 \%$ & 3.50 & 6.87 & $96 \%$ \\
\hline 3. & 3.50 & 0.00 & $100 \%$ & 3.50 & 0.00 & $100 \%$ \\
\hline 4. & 3.50 & 5.46 & $56 \%$ & 3.50 & 5.10 & $46 \%$ \\
\hline \multirow[t]{2}{*}{5.} & 3.50 & 0.00 & $100 \%$ & 3.50 & 4.70 & $34 \%$ \\
\hline & \multicolumn{2}{|c|}{ Rata-rata } & $70 \%$ & \multicolumn{2}{|c|}{ Rata-rata } & $67 \%$ \\
\hline
\end{tabular}

Setelah melakukan pengujian integrasi dengan variasi jarak 3,5 meter, maka dilanjutkan dengan melakukan pengujian pada variasi jarak 7 meter seperti yang ditunjukkan pada Tabel 8.

Tabel 8. Data GPS pengujian integrasi pada variasi jarak 7 meter

\begin{tabular}{|c|c|c|c|c|c|c|}
\hline \multirow[b]{2}{*}{ No } & \multicolumn{3}{|c|}{ Latitude } & \multicolumn{3}{|c|}{ Longitude } \\
\hline & $\begin{array}{c}\text { Seharusnya } \\
(\mathrm{m})\end{array}$ & $\begin{array}{c}\text { Aktual } \\
(\mathbf{m})\end{array}$ & Error & $\begin{array}{c}\text { Seharusnya } \\
\text { (m) }\end{array}$ & $\begin{array}{c}\text { Aktual } \\
(\mathbf{m})\end{array}$ & Error \\
\hline 1. & 7.00 & 7.58 & $8 \%$ & 7.00 & 7.71 & $10 \%$ \\
\hline 2. & 7.00 & 9.84 & $41 \%$ & 7.00 & 10.02 & $43 \%$ \\
\hline 3. & 7.00 & 8.30 & $19 \%$ & 7.00 & 8.13 & $16 \%$ \\
\hline 4. & 7.00 & 9.11 & $30 \%$ & 7.00 & 10.26 & $47 \%$ \\
\hline \multirow[t]{2}{*}{5.} & 7.00 & 0.00 & $100 \%$ & 7.00 & 0.00 & $100 \%$ \\
\hline & \multicolumn{2}{|c|}{ Rata-rata } & $40 \%$ & \multicolumn{2}{|c|}{ Rata-rata } & $43 \%$ \\
\hline
\end{tabular}

Untuk variasi jarak yang ketiga ialah pada jarak 11 meter ditunjukkan di Tabel 9.

Tabel 9. Data GPS pengujian integrasi pada variasi jarak 11 meter

\begin{tabular}{|c|c|c|c|c|c|c|}
\hline \multirow[b]{2}{*}{ No } & \multicolumn{3}{|c|}{ Latitude } & \multicolumn{3}{|c|}{ Longitude } \\
\hline & $\begin{array}{c}\text { Seharusnya } \\
(\mathbf{m})\end{array}$ & $\begin{array}{c}\text { Aktual } \\
(\mathbf{m})\end{array}$ & Error & $\begin{array}{c}\text { Seharusnya } \\
\text { (m) }\end{array}$ & $\begin{array}{c}\text { Aktual } \\
(\mathbf{m})\end{array}$ & Error \\
\hline 1. & 11.00 & 0.00 & $100 \%$ & 11.00 & 0.00 & $100 \%$ \\
\hline 2. & 11.00 & 0.00 & $100 \%$ & 11.00 & 12.10 & $10 \%$ \\
\hline 3. & 11.00 & 9.28 & $16 \%$ & 11.00 & 16.50 & $50 \%$ \\
\hline 4. & 11.00 & 12.50 & $14 \%$ & 11.00 & 12.88 & $17 \%$ \\
\hline \multirow[t]{2}{*}{5.} & 11.00 & 8.40 & $24 \%$ & 11.00 & 15.90 & $45 \%$ \\
\hline & \multicolumn{2}{|c|}{ Rata-rata } & $51 \%$ & \multicolumn{2}{|c|}{ Rata-rata } & $44 \%$ \\
\hline
\end{tabular}


Dari ketiga variasi jarak, yakni 3,5 meter, 7 meter, dan 11 meter pada pengujian integrasi untuk receiver GPS ini, didapatkan rata-rata kesalahan pada garis lintang ialah sebesar 53\% dan $51 \%$ pada garis bujur. kesalahan $100 \%$ pada percobaan terjadi karena kesalahan pembacaan receiver GPS 1 maupun GPS 2, sehingga tidak terdefinisi bahwa receiver GPS 2 pada quadcopter mendekati receiver GPS 1 pada modul pengguna.

\subsection{Pengujian Kecepatan Motor pada Quadcopter}

Tabel 10 dan Tabel 11 di atas merupakan hasil dari pengujian motor quadcopter pada percobaan dua percobaan terbang. Percobaan ke-1 dan ke-2. Dari kedua tabel tersebut, maka dapat dikatakan bahwa motor bergerak sesuai dengan perintah yang dikeluarkan modul pengguna dan juga sesuai dengan prinsip gerakan putar motor quadcopter dan perancangan lintasan pergerakan Quadcopter Berbasis GPS bisa diterapkan.

Tabel 10. Data kecepatan putar 4 motor quadcopter percobaan ke-1

\begin{tabular}{ccccc}
\hline Perintah & $\begin{array}{c}\text { Motor 1 } \\
(\mathbf{R p m})\end{array}$ & $\begin{array}{c}\text { Motor 2 } \\
(\mathbf{R p m})\end{array}$ & $\begin{array}{c}\text { Motor 3 } \\
(\mathbf{R p m})\end{array}$ & $\begin{array}{c}\text { Motor 4 } \\
(\mathbf{R p m})\end{array}$ \\
\hline Maju & 4411 & 3824 & 7616 & 9129 \\
\hline Mundur & 7438 & 7823 & 4677 & 5143 \\
\hline Kanan & 4757 & 7430 & 7336 & 4759 \\
\hline Kiri & 6970 & 2431 & 2358 & 6818 \\
\hline
\end{tabular}

Tabel 11. Data kecepatan putar 4 motor quadcopter percobaan ke-2

\begin{tabular}{ccccc}
\hline Perintah & $\begin{array}{c}\text { Motor 1 } \\
(\mathbf{R p m})\end{array}$ & $\begin{array}{c}\text { Motor 2 } \\
(\mathbf{R p m})\end{array}$ & $\begin{array}{c}\text { Motor 3 } \\
(\mathbf{R p m})\end{array}$ & $\begin{array}{c}\text { Motor 4 } \\
(\mathbf{R p m})\end{array}$ \\
\hline Maju & 2693 & 2578 & 7059 & 6003 \\
\hline Mundur & 4912 & 3512 & 1080 & 1530 \\
\hline Kanan & 2633 & 1398 & 1349 & 2005 \\
\hline Kiri & 3684 & 2462 & 2487 & 3978 \\
\hline
\end{tabular}

\section{KESIMPULAN}

Dari hasil perancangan, pembuatan serta pengujian sistem didapatkan beberapa kesimpulan, sebagai berikut:

1. Receiver GPS 1 user Ublox-Neo 6M dan GPS 2 Quadcopter yaitu U-blox-Neo 7M, mampu untuk mendapatkan data posisi dari satelit optimal di ruang terbuka.

2. Quadcopter SQ800C dapat terbang selama 23,37 menit dengan menggunakan baterai lipo 3,7 V dengan $1200 \mathrm{mAh}$.

3. Data GPS dari pengujian integrasi pergerakkan quadcopter untuk mendekati titik tujuan dimana pengguna berada pada variasi jarak 3,5 meter, 7 meter, dan 11 meter memiliki rata-rata kesalahan pada garis lintang sebesar $53 \%$ dan $51 \%$ pada garis bujur. 
4. Dengan menggunakan indikator pergerakan motor quadcopter yang bergerak sesuai dengan perintah yang dikeluarkan dari modul pengguna dan juga sesuai dengan prinsip gerakan putar motor quadcopter, perancangan lintasan pergerakan quadcopter berbasis GPS bisa diterapkan.

\section{REFERENSI}

[1] B. E. P. Purnama, "Pemanfaatan Global Positioning System Untuk Pelacakan Objek Bergerak," Sentra Penelit. Eng. dan Edukasi, vol. 2, no. 2, pp. 6-12, 2009.

[2] M. Nurdiansyah, "Perancangan dan Implementasi Kontroler PID untuk Tracking Waypoint pada Sistem Navigasi UAV ( Unmanned Aerial Vehicle ) Berbasis GPS ( Global Positioning System )," Semin. Tugas Akhir, pp. 1-8, 2011.

[3] R. Handayani, M. I. Sari, A. A. G. Agung, F. Ramdana, and A. Wahyudi, "Alert, monitoring and tracking for electronic device prototype," Proceeding 2017 11th Int. Conf. Telecommun. Syst. Serv. Appl. TSSA 2017, vol. 2018-January, pp. 1-4, 2018.

[4] A. H. Abdur Rohman Harits Martawireja, "Pemodelan driving cycle dengan menggunakan model polinomial untuk sepeda motor," Universitas Indonesia, 2016.

[5] L. Fdu et al., "2018 2nd IEEE Advanced Information Management,Communicates,Electronic and Automation Control Conference(IMCEC 2018)," no. Imcec, pp. 1783-1787, 2018. 